Středoevropské politické studie / Central European Political Studies Review www.journals.muni.cz/cepsr

Ročník XIX (2017), Číslo 1, s. 25-54 / Volume XIX (2017), Issue 1, pp. 25-54 (c) Mezinárodní politologický ústav / International Institute of Political Science DOI: $10.5817 / C E P S R .2017 .1 .25$

\title{
Voter policy emphasis and party electoral manifestos: Assessing parties' reflections of voter policy shifts in the 2010 and 2013 Czech parliamentary elections
}

\author{
LENKA HOMOLKOVÁ ${ }^{1}$
}

\begin{abstract}
The party manifesto is a crucial document identifying a party's ideological position. Measuring the response of political party manifestos to both the mean voter as well as party constituency positions remains extensively difficult given the lack of available data, but also the complex political realities and factors which the parties must take into consideration e.g. the economy, globalization, the demands of the market, and pressure from rival parties. In spite of these complexities, this article analyses the extent to which political parties reflect voter policy emphasis in their political manifestos. Through the content analysis of electoral manifestos the article determines the policy positions of $C_{z e c h}$ political parties during the 2010 and 2013 elections to the Lower House of the Parliament. Identifying also key voter policy preferences the article looks into the possible congruence between shifts in voter emphasis and changes in party electoral manifestos. Employing an approach not yet fully applied in academic research, the article examines shifts within ideological space, while focusing also on specific key policy areas. It concludes that in the short term - from the 2010 to 2013 parliamentary elections in the Czech Republic - political parties responded to shifts in voter policy emphasis in just one quarter of cases. The responsiveness differed significantly from one party to another.
\end{abstract}

Keywords: Voter Policy Emphasis; Electoral Manifesto, Party Position Shift, Comparative Manifesto Project

\section{Introduction}

Citizens vote for political parties which they identify with, which they think best reflect their interests, and which are the most likely to change their position in the

${ }^{1}$ Ph.D. candidate in Political Science, Faculty of Social Studies, Masaryk University, Joštova 10, 60200 Brno, Czech Republic. E-mail: homolkova.lenka@gmail.com. 
preferred direction (Busch 2016; Merrill and Grofman 1999: 17-32). If political parties want to be re-elected, they must shape their electoral manifestos to respond to shifts in voter policy emphasis (Budge 1994; Stimson 1995). Widely populated areas of academic research have been devoted to examining the different incentives to which parties may or may not respond. While in the long run, the left-right position of political parties remains relatively stable, parties are said to be highly responsive to shifts in the electorate's priorities.

The electoral program or party manifesto is a crucial document for identifying a party's ideological position. Comparing manifestos from one election to another helps to identify party policy position shifts (Busch 2016; Adams et al. 2011). In its electoral manifesto, a political party defines and responds to the needs and preferences of the electorate. The degree to which parties reflect voter policy emphasis, nevertheless, remains an extremely complex question, as many other factors influence electoral programs. It is difficult to isolate shifts in party policy in response to voter emphasis from other aspects of the electoral and political process (Kunštát 2004).

In spite of these complexities, this article analyses the extent to which political parties reflect on the policy emphasis of voters in their electoral manifestos, using the case of the last two Czech parliamentary elections. Reflecting a wider body of research on the ideological congruence of voter policy preferences with those of their party representatives, it tests the salience of political issues prior to the election to demonstrate how much parties respond to short term shifts in public opinion (Klingemann et al. 2006; Budge and McDonald 2012; Warwick 2010; Walczak et al. 2012). Through content analysis of electoral manifestos, employing the Comparative Manifesto Project (CMP) methodology, this article determines the policy preferences of Czech political parties during the 2010 and 2013 elections to the Lower House of the Parliament. By means of the Eurobarometer, STEM and The Centre for public opinion research surveys, the article analyses short-term shifts in policy emphasis on the part of the Czech electorate. Based on the main topics emphasised by the voters, this article looks into possible congruence between voter emphasis shifts and changes in electoral manifestos.

First, the article explores existing academic research and reveals that the extent to which parties respond to shifts in voter emphasis remains a relatively "disputed area". With the aim of filling the existing gap, the article establishes a complex methodology to examine how Czech political parties reflected in their electoral manifestos short-term shifts in voter policy emphasis (from 2010 to 2013 elections) in the ideological space in general, but also within key policy areas.

At the very beginning of the analysis, the article classifies Czech political parties that contested seats in 2010 and 2013 parliamentary elections on the left-right scale. Then, it identifies key policy areas which the voters indicated as the most important to them. In this part, the article works with the Eurobarometer survey and aims to 
find similarities between electoral manifestos and voter emphasis. Furthermore, it employs survey analysis to fill potential gaps and provide data for the quantitative research.

The paper concludes that in the short term, political parties responded to shifts in voter policy emphasis in just one-quarter of cases. The congruence between parties' and electorate's position shifts, however, remains inconsistent and differs from party to party. Given that this research focuses solely on short-term partyelectorate shifts, the results support the assumption that parties' ideological shifts tend to occur over the long-term. Further comparative and more systematic research into the congruence between shifts in voter policy emphasis and the manifestos of political parties both in the short- and long-term would allow further examination of the behaviour of political parties and fill some gaps in existing academic research.

\section{Theoretical considerations and hypothesis}

Relatively extensive academic research has focused on the different incentives to which parties could respond in their electoral manifestos. Factors that parties are shown to respond to include the policy shifts of other parties; past election results, notably electoral defeats; changes in leadership; as well as global factors, such as the economy, globalization or migration (Leimgruber et al. 2010; Schumacher et. al. 2013: 4-5; Meyer 2013: 209-215; Ezrow 2014). Research by Lawrence Ezrow (2014) also demonstrates that the need to balance public demands with the pressure of the market influences the responsiveness of political parties to shifts in voter emphasis. In addition, Fossati and Hausermann (2014) found that the level of income distribution also contributes to voter choice and therefore would play a role in re-shaping party policy. Parties had to respond to such developments and shape their policies vis-à-vis social investment strategies.

Scholars also extensively examined the question of which type of voters parties responded to (Adams et al. 2006; Meguid 2008; Ezrow et al. 2011). Ezrow et al. (2011) examined two models reflecting party response to voter emphasis shifts. In doing so, they first distinguished between niche parties - the parties that direct their focus on a smaller group of voters embracing a certain particular policy or ideology and usually do not coincide with the existing lines of political division, e.g. Communist parties, Green parties, extreme right parties, etc. - and mainstream parties, which are inclined to shift the political centre (Adams 2006: 513-529; Megiud 2005: 347-348; Wagner 2010: 5-7). Overall, parties respond to shifts in the preferences of their supporters (partisan constituency model) or shifts in the mean voter position (general electorate model). Comparing 15 policy programs in 15 countries from 1973 to 2002, Ezrow et al. discovered that a general electorate model characterised the policy shifts of the mainstream parties, while a partisan 
constituency model was rather typical for the Communist, Green and extremist nationalist parties. In some cases, however, niche parties may also - in response to voters - shift their positions slightly towards the mainstream political base leaning more towards the general electorate model (Ezrow 2014).

The parties also operate in an ideological space and focus on specific policy areas that they consider important to the voters. The position in the ideological space, the left-right position, is said to remain largely stable over time. Shifts within individual party policy preferences presumably reflect shifts in voter policy emphasis (Budge 1994; Schumacher et al. 2013). This article works exclusively with the left-right dimension to analyse a party's orientation in the ideological space. It is worth noting, however, that numerous different approaches such as the proximity-distance dimension were introduced to examine interactions between parties and voters in the Czech ideological space (Chytilek and Eibl 2011: 6-64).

Party responses to shifts in public opinion remain a disputed area. Whereas Adams et al. (2004), Somer-Topcu (2009) and Ezrow (2010) presuppose that parties are expected to follow shifts in public opinion, Meyer (2013: 209-215) concludes the opposite. In Meyer's conclusions, public opinion shifts do not lead to changes in party policy positions.

This article focuses on shifts not only in the ideological space, but also within key policy areas, which are reflected mostly in public opinion. Examining parties' responses to voter shifts in key policy areas has yet to be attempted in wider more systematic academic research. The article aims to explore the possibilities and relevance of such an approach.

Taking into account previous research including for example Ezrow (2011), this article takes note of niche parties and mainstream parties on the left-right scale and partisan constituency and general electorate models. It proceeds on the assumption that a party's position in key policy areas changes more rapidly from one election to another without affecting the ideological position and long-term policies of the party. The paper seeks to address the question of the extent to which Czech political parties reflected short-term voter policy emphasis.

\section{Methodology}

The methodology is divided into two main parts - quantitative analysis and survey analysis. Firstly, it focuses on the classification of Czech political parties. To place parties on the left-right scale, this article works with the Comparative Manifesto Project (CMP) dataset (Volkens et al. 2016). Employing content analysis and encoding different topics appearing in the electoral programs of different political parties, CMP measures the policy positions of parties participating in elections. Comparing the 2010 and 2013 electoral manifestos of individual parties allow us to identify main policy shifts in parties' ideological positions (Volkens et al. 2016; Klingemann et al. 2006; Budge et al. 2001). Voter emphasis is coded to assess the 
possible congruence with party manifestos. Employing directional analysis, a methodology is established to examine the congruence between shifts in voter policy positions and changes in party manifestos. Secondly, the methodological part focuses on survey analysis to remedy the absence of data required for full quantitative research.

\section{a. Quantitative analysis: coding the data}

\section{CLASSIFYING POLITICAL PARTIES ON THE LEFT-RIGHT SCALE}

In the first part, the article classifies political parties on the left-right scale, categorising mainstream and niche parties. The left-right approach was selected due to its measurability and the compatibility of the respective data with other parts of the research. Studies of other dimensions of ideological space presented, for example, by Chytilek and Eibl (2011) go beyond the scope of this article.

The left-right classification employs the CMP methodology as originally presented by Laver and Budge (1992). The CMP project is based on the content analysis of individual political party manifestos. The human coders classify each reference in political party manifestos to one of 56 categories (see Appendix I for the detailed description of individual categories).

Only 26 categories are considered relevant by the CMP for determining the left-right position of political parties (see Table 1 below). A specific formula is used, taking into account the percentage of references made by the political party in each of the relevant categories:

\section{$(\mathrm{R}-\mathrm{L})$}

In the formula, $\mathrm{R}$ represents the percentage of references made in the party manifesto that are classified under the right category, while $\mathrm{L}$ represents left category statements (Volkens et al. 2016: 29; Budge 2013: 4-5). Accordingly, in this study, the position of each party was determined on the left-right scale for both the 2010 and 2013 elections. To assess the congruence between left-right shifts in party position and left-right shifts in voter emphasis, I encoded voter emphasis using the same methodology and on the basis of information available from the Eurobarometer survey.

Eurobarometer is a public opinion survey addressing a variety of topics. The standard Eurobarometer survey, as used for the purposes of this article, is conducted every autumn and spring and represents a series of cross-national longitudinal studies aimed at comparing trends across the European Union. The data is also broken down by individual state. This article works with one single question identified in the survey. In the question, respondents select three policy areas they currently emphasise as the most important. The policy areas as identified by the respondents are then encoded by the author in the same way as in the CMP 
to determine the positions of voters on the left-right scale according to their policy emphasis.

Table 1: Determinants of the political party position on the left-right scale

\begin{tabular}{|c|c|}
\hline RIGHT EMPHASSES: sum of $\%$ for & LEFT EMPHASES: sum of $\%$ for \\
\hline External relations - military positive (code 104) & External relations - anti-imperialism (code 103) \\
\hline $\begin{array}{l}\text { Freedom and democracy - human rights positive } \\
\text { (code 201) }\end{array}$ & External relations - military negative (code 105) \\
\hline $\begin{array}{l}\text { Freedom and democracy - Constitutionalism } \\
\text { positive (code 203) }\end{array}$ & External relations - peace positive (code 106) \\
\hline $\begin{array}{l}\text { Political system - political authority positive } \\
\text { (code 305) }\end{array}$ & $\begin{array}{l}\text { External relations - internationalism positive } \\
\text { (code 107) }\end{array}$ \\
\hline $\begin{array}{l}\text { Economy - free market economy positive (code } \\
\text { 401) }\end{array}$ & Freedom and democracy - democracy (code 202) \\
\hline Economy - incentives positive (code 402) & $\begin{array}{l}\text { Economy - market regulation positive (code } \\
403 \text { ) }\end{array}$ \\
\hline Economy - protectionism negative (code 407) & $\begin{array}{l}\text { Economy - economic planning positive (code } \\
404 \text { ) }\end{array}$ \\
\hline $\begin{array}{l}\text { Economy - economic orthodoxy positive (code } \\
\text { 414) }\end{array}$ & Economy - protectionism positive (code 406) \\
\hline $\begin{array}{l}\text { Welfare and quality of life - welfare state } \\
\text { limitation (code 505) }\end{array}$ & Economy - controlled economy (code 412) \\
\hline $\begin{array}{l}\text { Fabric of society - national way of life positive } \\
\text { (code 601) }\end{array}$ & Economy - nationalisation (code 413) \\
\hline $\begin{array}{l}\text { Fabric of society - traditional morality positive (code } \\
603 \text { ) }\end{array}$ & $\begin{array}{l}\text { Welfare and quality of life - welfare state } \\
\text { expansion (code 504) }\end{array}$ \\
\hline Fabric of society - law and order (code 605) & $\begin{array}{l}\text { Welfare and quality of life - education expansion } \\
\text { (code 506) }\end{array}$ \\
\hline $\begin{array}{l}\text { Fabric of society - civic mindedness positive } \\
\text { (code 606) }\end{array}$ & $\begin{array}{l}\text { Social groups - labour groups positive (code } \\
701 \text { ) }\end{array}$ \\
\hline
\end{tabular}

Data source: Budge 2013; Volkens et al. 2016: 29.

Note: The codes indicate individual policy areas as established in the CMP. They are further used throughout the article.

Party manifesto data and public opinion survey data are largely asymmetric. The research, therefore, does not allow working with absolute numbers. Comparison only remains possible in determining the directions of shifts in party policies and public opinion. 


\section{DETERMINING POSITIONS OF POLITICAL PARTIES WITHIN THE MAIN SEVEN} POLICY AREAS

Using the CMP methodology, this article works with seven main policy areas external relations; freedom and democracy; the political system; the economy; the welfare state and quality of life; the fabric of society; and social groups. Each of the areas has several categories, amounting to 56 different policy issues examined under each category (Volkens et al. 2016: 8). Firstly, shifts in positions reflected in parties' electoral manifestos within these categories are examined. Secondly, using the same data from the Eurobarometer survey, shifts in voter emphasis are analysed in a similar way. Voter emphases are coded according to the CMP scheme. This is a relatively new approach as no academic research so far has attempted to code voter emphasis in individual CMP categories and match them with political party manifestos.

\section{CONGRUENCE OF SHIFTS IN VOTER POLICY POSITIONS AND CHANGES IN PARTY MANIFESTOS}

The dependent variable is the position shift of a party along the left-right scale, as well as within each of the above seven categories. Firstly, the position of the party during the 2013 elections is compared to its position during the 2010 elections. The party position change variable indicates that a party shifted its position, firstly, on the left-right scale, and, secondly, within each of the policy areas.

The data from the Eurobarometer survey are used to measure shifts in the mean voter position. The mean voter position is determined in the quantitative part of the research. The survey highlights voters' policy preferences by depicting policy areas that voters indicated as most important. The mean voter position is determined by comparing the mean position on the left-right scale as well as within each of the seven policy areas in the 2013 elections with the corresponding positions for the 2010 elections. The results indicate the congruence between voter policy emphasis shifts and changes in party manifestos.

Furthermore, the article employs directional analysis comparing the policy direction of the electorate shift with the direction of the party shift within each of the seven policy areas and identified sub-categories. The congruence of the party policy shift with the voter emphasis shift is subsequently calculated on a scale from (1), indicating the same direction for both with a percentage difference lower than $5 \%$, to $(-1)$, indicating different directions for each with a difference higher than $5 \%$ (see Table 2). The value $(0)$ is accorded in the case of a voter shift that is not reflected at all in the party manifesto. Should both the voter emphasis and the party position remain unchanged, the value (1) is assigned. 
Table 2: Directional analysis - congruence between voters and party shifts

\begin{tabular}{|c|c|c|}
\hline aValue & Direction of policy shift & Difference of the shift \\
\hline 1 & $\begin{array}{l}\text { Party shift in policy direction reflects the } \\
\text { voter shift }\end{array}$ & $\begin{array}{l}\text { Difference in party and voter shifts }<5 \\
\%\end{array}$ \\
\hline 0.5 & $\begin{array}{l}\text { Party shift in policy direction reflects the } \\
\text { voter shift }\end{array}$ & $\begin{array}{l}\text { Difference in party and voter shifts } \\
=/>5 \%\end{array}$ \\
\hline 0 & $\begin{array}{l}\text { Party position does not change in spite } \\
\text { of the voter shift }\end{array}$ & $\mathrm{N} / \mathrm{A}$ \\
\hline-0.5 & $\begin{array}{l}\text { Party shift in policy direction goes } \\
\text { against the voter shift }\end{array}$ & $\begin{array}{l}\text { Difference in party and voter shifts }<5 \\
\%\end{array}$ \\
\hline-1 & $\begin{array}{l}\text { Party shift in policy direction goes } \\
\text { against the voter shift }\end{array}$ & $\begin{array}{l}\text { Difference in party and voter shifts } \\
=/>5 \%\end{array}$ \\
\hline
\end{tabular}

Data source: The content of the table was developed by the author on the basis of the methodology devised by Merrill and Grofman (1999).

\section{b. Survey analysis}

While only Eurobarometer allows mean voter emphasis in various policy categories to be quantified, the quantitative research is limited to this data. Data from the STEM and CVVM surveys are used to look into voter emphasis and shifts in party manifestos employing survey analysis. Survey analyses are used to fill potential gaps in the quantitative research. Both STEM and CVVM look into voter satisfaction within specific policy areas (e.g. democracy, EU membership, the economic situation, and quality of life). By employing survey analysis, the article examines the extent to which party manifestos reflect changes in the mood of voters in these policy areas.

\section{c. Limits of the research}

Critics have argued that initial left-right measurements of party positions are not concerned with qualities of electoral manifestos and proposed alternatives. The coding may affect the position of the party on the left-right scale. Nevertheless, the aim of the CMP is primarily to allow comparisons in party position shifts over time (Klingemann et al. 2006; Lowe et al. 2011; Benoit et al. 2012; Budge 2013). Similarly, other research projects examined the possibility of using the CMP to compare voter emphasis with party positions (Chytilek 2014: 67-70). In his latest contribution, Budge (2013: 7-8) offers possible alternatives to the right-left measurement; however, he also notes that a consensus has formed that whoever uses the methodology should implement it as it fits his or her research. Given that the rightleft measurement constitutes only one part of this research, which is complemented by the further assessment of party manifestos in all seven thematic categories, the original methodology is fit for the purpose. Therefore, a party's left-rightposition is 
determined by considering a number of statements each party makes in its manifesto within the individual categories (see Table 1).

The Eurobarometer survey only presents the policy areas that voters feel strongest about. These areas do not reflect all categories determined by the CMP, which would leave the research incomplete as it only allows comparison in five policy areas. The qualitative analysis focuses mainly on democracy, one of the areas not primarily covered by Eurobarometer survey's respondents. It aims to complete this gap within the existing body of research.

Similarly, the other analysed surveys only present shifts in party constituency satisfaction in the policy areas of quality of life and democracy. Party constituency emphasis is, however, not reflected in the Eurobarometer survey covering all policy areas of the CMP. Therefore, the party constituency shift in these areas cannot be fully quantified in this research article. The extent to which the party reflects a shift in party constituency position - more specifically, the shift in the level of voter satisfaction with respect to a specific policy area - is determined by looking into changes in party manifestos between the 2010 and 2013 elections in the specific policy area.

The research only focuses on the extent to which party manifestos reflect shifts in voter preferences in the short term - from one election (2010) to another (2013). Therefore, the results only reflect the immediate party shifts. The results can potentially be different in the long run, as parties face constraints while moving from the status quo (Meyer 2013: 209-215). Long-term observations go beyond the scope of this article.

Similarly, this article uses Eurobarometer survey data that was issued right before the elections, raising the question as to whether parties had enough time to familiarise themselves with the data and reflect it in their programs. This approach is, however, unlikely to affect the results of the research, assuming that the Eurobarometer survey reflects the general longer-term voter emphasis prior to the vote. The article does not calculate potential radical shifts in voter emphasis based on immediate political events; this is a topic for separate research.

The lack of available data on shifts in voter emphasis as broken down per particular party does not allow for a full examination of how parties reflect voter changes in their political manifestos. The analysis thus only touches upon this issue in the qualitative part. The article takes into consideration partisan constituency and general electorate models, however, the results cannot be fully quantified. In addition, the data in the article has been collected from different sources; thus, an ordinal rather than a cardinal approach is required. The analysis therefore focuses more on the tendencies and directions of party position shifts, rather than the comparison of absolute numbers. Possible measurement errors in public opinion shifts may present another obstacle (Meyer 2013: 214-215). 


\section{Determining the policy positions of the Czech political parties contesting the 2010 and 2013 parliamentary elections and their congruence with voter policy emphasis}

The last two national-level elections to the Lower House of the Parliament took place on 28-29 May 2010, and on 25-26 October 2013. The period between these elections witnessed significant changes to the Czech political landscape, similar to the changes experienced by some post-communist countries in Europe during the past two decades. The strong post-communist parties, the liberal-conservative Civic Democratic Party (Občanská demokratická strana; ODS) and the Czech Social Democratic Party (Ceská strana sociálně demokratická; ČSSD) achieved historic lows in the 2010 elections in comparison to 2006 and their support has continued to decline. The Christian Democratic Party - Czechoslovak People's Party (Krest'anskodemokratická unie - Ceskoslovenská strana lidová; KDU-ČSL) and the Green Party (Strana zelených) failed to reach the $5 \%$ threshold to enter Parliament, while the new parties Tradition, Responsibility and Prosperity 09 (Tradice Odpovédnost Prosperita 2009; TOP09) and Public Affairs (Véci verejnê) won sufficient parliamentary representation to join the coalition with the ODS.

The 2013 elections brought even greater changes. Of the two largest parties, CSSD gained the lowest number of votes since 1992 and ODS entered Parliament with as little as $7.72 \%$. KDU-ČSL regained parliamentary representation and two new parties gained enough votes to enter Parliament: ANO2011 and the Dawn of Direct Democracy of Tomio Okamura, a niche party inclining towards the extreme right (Maškarinec and Bláha 2014: 706-707; Havlík 2016: 185-186).

Only six political parties contested both elections: the Green Party; the Communist Party of Bohemia and Moravia (Komunistická strana Cech a Moravy; KSČM); ČSSD; ODS; KDU-ČSL; and TOP09 (Volkens 2016a). For reasons of comparison, only the parties that contested both elections represent the main subject of the research.

\section{a. Assessment on the left-right scale}

To begin, the left-right scale was applied to the parties that contested both 2010 and 2013 elections. Analysing their programs by employing the CMP methodology, Table 3 depicts the policy preference in party manifestos in 2010 and 2013 within the seven main categories (areas) and their sub-categories (sub-areas) relevant for the left-rightdetermination (as outlined in Table 1) (Volkens 2016: 29).

A similar analysis was conducted for voter policy preferences using the data from the 2010 and 2013 Eurobarometer surveys specific to the Czech Republic (Eurobarometer 2010, 2013). Following the CMP methodology, voter policy preferences expressed in the survey were coded as per Table 4. The numbers 
attached to each policy preference reflect, in percentages, the importance voters attach to each area. Given that the survey respondents were asked to select two policy issues which they consider the most important at the national level, the percentage in Table 4 attached to each policy area was re-calculated by the author on a 1-100 scale (see Apendix 1 for the original Eurobarometer survey data). Data reflect the situation before the 2010 and 2013 elections. 
Table 3: Policy preferences in party manifestos

\begin{tabular}{|c|c|c|c|c|c|c|c|c|c|c|c|c|}
\hline & \multicolumn{2}{|c|}{ ODS } & \multicolumn{2}{|c|}{ KDU-ČSL } & \multicolumn{2}{|c|}{ TOP09 } & \multicolumn{2}{|c|}{ ČSSD } & \multicolumn{2}{|c|}{ Green party } & \multicolumn{2}{|c|}{ KSČM } \\
\hline & 2010 & 2013 & 2010 & 2013 & 2010 & 2013 & 2010 & 2013 & 2010 & 2013 & 2010 & 2013 \\
\hline External relations - military positive (104) & 2.35 & 4.44 & 6.48 & 1.49 & 1.98 & 1.46 & 0.94 & 1.74 & 0,44 & 0,23 & 0,73 & 1,49 \\
\hline Freedom and democracy - human rights positive (201) & 3.49 & 3.81 & 1.88 & 3.57 & 1.16 & 2.43 & 2.35 & 1.09 & 3,34 & 3,46 & 1,83 & 2,97 \\
\hline Freedom and democracy - Constitutionalism positive (203) & 0 & 0.63 & 0.6 & 0 & 0 & 1.13 & 0 & 0 & 0 & 0 & 0.73 & 0 \\
\hline Political system - political authority positive (305) & 2.6 & 0.32 & 0.6 & 0 & 0.99 & 0 & 1.56 & 0 & 0.44 & 0 & 2.56 & 0 \\
\hline Economy - free market economy positive (401) & 4.55 & 3.65 & 1.11 & 0.3 & 3.14 & 0.81 & 0.16 & 0 & 0.88 & 0.46 & 0 & 0 \\
\hline Economy - incentives positive (402) & 3.73 & 9.37 & 1.19 & 2.38 & 1.16 & 3.24 & 2.66 & 1.74 & 1.01 & 1.38 & 1.83 & 1.49 \\
\hline Economy - protectionism negative (407) & 0 & 0 & 0 & 0 & 0.17 & 0.81 & 0 & 0 & 0 & 0 & 0 & 0 \\
\hline Economy - economic orthodoxy positive (414) & 3.17 & 0 & 0 & 0.6 & 4.46 & 3.73 & 1.25 & 0.44 & 2.4 & 0.23 & 0 & 0 \\
\hline Welfare and quality of life - welfare state limitation (505) & 2.6 & 2.7 & 0.6 & 1.49 & 4.95 & 0.81 & 0 & 0.22 & 0.57 & 0.23 & 0 & 0 \\
\hline Fabric of society - national way of life positive (601) & 0.49 & 0.63 & 0 & 0.3 & 0 & 0.65 & 0 & 0.22 & 0 & 0 & 0.73 & 1.49 \\
\hline Fabric of society - traditional morality positive (603) & 1.87 & 0.32 & 6.4 & 1.19 & 1.98 & 2.11 & 1.56 & 0.87 & 1.7 & 0.69 & 1.47 & 0.37 \\
\hline Fabric of society - law and order (605) & 5.84 & 4.76 & 10.07 & 5.36 & 8.09 & 3.73 & 9.55 & 5.66 & 4.79 & 0.92 & 8.79 & 6.32 \\
\hline Fabric of society - civic mindedness positive (606) & 0 & 0.16 & 1.02 & 0.6 & 0 & 3.57 & 0.16 & 0.22 & 0.57 & 0.69 & 0 & 0.74 \\
\hline R-total & 30.68 & 30.79 & 29.95 & 17.26 & 28.05 & 24,47 & 20.19 & 12.2 & 16.15 & 8.29 & 18.68 & 14,87 \\
\hline External relations - anti-imperialism (103) & 0.65 & 0 & 0 & 0 & 0.17 & 0 & 0 & 0 & 0.38 & 0 & 1.47 & 0 \\
\hline External relations - military negative (105) & 0 & 0 & 0 & 0 & 0 & 0 & 0.78 & 0 & 0.25 & 0.46 & 2.2 & 2.97 \\
\hline External relations - peace positive (106) & 0.08 & 0.32 & 0 & 0.3 & 0 & 0.16 & 0.63 & 0 & 0.19 & 0.23 & 0.73 & 1.12 \\
\hline External relations - internationalism positive (107) & 2.68 & 1.75 & 0.26 & 2.08 & 1.32 & 1.3 & 2.03 & 1.09 & 2.84 & 1.38 & 1.1 & 2.23 \\
\hline Economy - market regulation positive (403) & 2.44 & 6.35 & 5.72 & 8.93 & 4.29 & 3.08 & 2.66 & 4.79 & 8.45 & 10.37 & 8.42 & 8.18 \\
\hline Economy - economic planning positive (404) & 0 & 3.02 & 0 & 1.19 & 0 & 1.46 & 0.31 & 1.09 & 0.06 & 0.69 & 0.73 & 2.23 \\
\hline Economy - protectionism positive (406) & 0.16 & 1.75 & 1.19 & 1.19 & 1.16 & 0.16 & 1.56 & 2.18 & 0.63 & 2.3 & 0.73 & 1.49 \\
\hline Economy - controlled economy (412) & 0.08 & 0 & 0.26 & 0.89 & 0.17 & 0.32 & 0.31 & 0.22 & 0.19 & 1.15 & 1.83 & 3.35 \\
\hline Economy - nationalisation (413) & 0.32 & 2.22 & 0 & 0 & 0.33 & 0.16 & 1.41 & 0.22 & 0.44 & 0.46 & 1.47 & 1.12 \\
\hline Welfare and quality of life - welfare state expansion (504) & 8.36 & 10.79 & 6.57 & 11.01 & 6.6 & 8.43 & 11.11 & 11,98 & 8.77 & 8.99 & 16.12 & 11.9 \\
\hline Welfare and quality of life - education expansion (506) & 2.52 & 2.86 & 5.72 & 5.65 & 4.13 & 6.16 & 3.76 & 3.7 & 5.3 & 4.15 & 5.13 & 6.32 \\
\hline Social groups - labour groups positive (701) & 0.08 & 3.02 & 0.09 & 3.87 & 0 & 1.46 & 1.1 & 4.36 & 0.13 & 0.92 & 1.1 & 3.72 \\
\hline Freedom and democracy - democracy (202) & 4.22 & 3.65 & 5.46 & 5.65 & 3.63 & 11.35 & 6.57 & 4.36 & 8.83 & 8.53 & 9.52 & 8.55 \\
\hline L-total & 21.59 & 35.71 & 25.26 & 40.77 & 21.78 & 34.04 & 32.24 & 33,99 & 36.47 & 39.63 & 50.55 & 53.16 \\
\hline
\end{tabular}

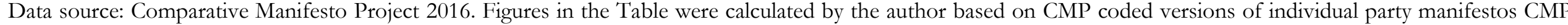
available at https://visuals.manifesto-project.wzb.eu/mpdb-shiny/cmp_dashboard_dataset/\#. 
Table 4: Coding voter policy emphasis prior to the 2010 and 2013 elections

\begin{tabular}{|l|l|l|l|}
\hline \multicolumn{3}{|c|}{ May-10 } & May-13 \\
\hline Unemployment & 25.51 & 23.16 & 7. Social groups (701. Labour groups: positive) \\
\hline $\begin{array}{l}\text { Economic } \\
\text { situation }\end{array}$ & 27.04 & 18.95 & 4. Economy (408. Economic goals) \\
\hline Crime & 8.67 & 7.37 & 6. Fabric of society (605. Law and order: positive) \\
\hline $\begin{array}{l}\text { Rising } \\
\text { prices/inflation }\end{array}$ & 11.22 & 15.79 & $\begin{array}{l}\text { 4. Economy (412. Controlled economy - control } \\
\text { over prices) }\end{array}$ \\
\hline $\begin{array}{l}\text { Healthcare/social } \\
\text { security }\end{array}$ & 6.63 & 5.79 & $\begin{array}{l}\text { 5. Welfare and quality of life (504. Welfare state } \\
\text { expansion) }\end{array}$ \\
\hline Immigration & 2.04 & 1.58 & $\begin{array}{l}\text { 6. Fabric of society (601. National way of life: } \\
\text { immigration) }\end{array}$ \\
\hline $\begin{array}{l}\text { Pensions } \\
\text { Taxation }\end{array}$ & 7.14 & 7.37 & $\begin{array}{l}\text { 5. Welfare and quality of life (504. Welfare state } \\
\text { expansion) }\end{array}$ \\
\hline $\begin{array}{l}\text { The educational } \\
\text { system }\end{array}$ & 2.55 & 3.16 & 4. Economy (402. Incentives: positive) \\
\hline Housing & 2.55 & 1.58 & $\begin{array}{l}\text { 5. Welfare and quality of life (506. Education } \\
\text { expansion) }\end{array}$ \\
\hline Terrorism & 3.57 & 2.11 & $\begin{array}{l}\text { 5. Welfare and quality of life (504. Welfare state } \\
\text { expansion) }\end{array}$ \\
\hline The environment & 1.02 & 0.53 & 1. External relations (104. Military positive) \\
\hline Energy & 1.02 & 0.00 & $\begin{array}{l}\text { 5. Welfare and quality of life (501. Environmental } \\
\text { protection) }\end{array}$ \\
\hline $\begin{array}{l}\text { Defence/Foreign } \\
\text { Affairs }\end{array}$ & 0.51 & 0.00 & $\begin{array}{l}\text { 5elfare and quality of life (501. Environmental } \\
\text { protection) }\end{array}$ \\
\hline Government debt & & 11.58 & 4. External relations (104. Military positive) \\
\hline
\end{tabular}

Data source: Author's own calculations based in Eurobarometer (2010, 2013) and Volkens et al. (2016) data and methodology.

Table 5 shows the policy preferences of voters and their shifts from one election to another. As indicated above, the left-right determination methodology does not work with all policy data, but selects only specific sub-categories (Volkens 2016: 29). The calculation reflects the data collected in Table 4 depicting only these relevant sub-categories. On the right $(\mathrm{R})$ scale, voters accorded their emphases to the following areas: 104 - military positive, 402 - incentives positive, 414 reduction of budget deficits, 601 - national way of life: immigration, and 605 - law and order positive. On the left (L) scale, voters emphasized the following areas: 412 - controlled economy, 504 - welfare state expansion, 506 - education expansion, and 701 - labour groups positive. The data in Table 5 show the cumulative importance, in percentages, that voters attributed to each of the sub-categories relevant to the left-right determination. As mentioned above, the Eurobarometer survey does not provide data from all the categories relevant to the left-right determination. Given, however, that the survey depicts the policy areas perceived 
by the voters as the most important, the information available is sufficient for the purpose of this article.

Table 5: Voter policy emphasis close to 2010 and 2013 parliamentary elections

\begin{tabular}{|c|c|c|c|c|c|}
\hline Code & 2010 & 2013 & Code & 2010 & 2013 \\
\hline $\begin{array}{l}\text { External relations - military positive } \\
\text { (104) }\end{array}$ & 1.02 & 0.53 & $\begin{array}{l}\text { External relations - anti- } \\
\text { imperialism (103) }\end{array}$ & & \\
\hline $\begin{array}{l}\text { Freedom and democracy - human } \\
\text { rights positive (201) }\end{array}$ & & & $\begin{array}{l}\text { External relations - military } \\
\text { negative (105) }\end{array}$ & & \\
\hline $\begin{array}{l}\text { Freedom and democracy - } \\
\text { Constitutionalism positive (203) }\end{array}$ & & & $\begin{array}{l}\text { External relations - peace } \\
\text { positive (106) }\end{array}$ & & \\
\hline $\begin{array}{l}\text { Political system - political authority } \\
\text { positive ( } 305)\end{array}$ & & & $\begin{array}{l}\text { External relations - } \\
\text { internationalism positive } \\
(107)\end{array}$ & & \\
\hline $\begin{array}{l}\text { Economy - free market economy } \\
\text { positive (401) }\end{array}$ & & & $\begin{array}{l}\text { Economy - market regulation } \\
\text { positive (403) }\end{array}$ & & \\
\hline Economy - incentives positive (402) & 2.56 & 3.16 & $\begin{array}{l}\text { Economy - economic } \\
\text { planning positive (404) }\end{array}$ & & \\
\hline $\begin{array}{l}\text { Economy - protectionism negative } \\
(407)\end{array}$ & & & $\begin{array}{l}\text { Economy - protectionism } \\
\text { positive (406) }\end{array}$ & & \\
\hline $\begin{array}{l}\text { Economy - economic orthodoxy } \\
\text { positive (414) }\end{array}$ & 0 & 11.58 & $\begin{array}{l}\text { Economy - controlled } \\
\text { economy (412) }\end{array}$ & 11.28 & 15.79 \\
\hline $\begin{array}{l}\text { Welfare and quality of life - welfare } \\
\text { state limitation (505) }\end{array}$ & & & $\begin{array}{l}\text { Economy - nationalisation } \\
\text { (413) }\end{array}$ & & \\
\hline $\begin{array}{l}\text { Fabric of society - national way of } \\
\text { life positive (601) }\end{array}$ & 2.05 & 1.58 & $\begin{array}{l}\text { Welfare and quality of life - } \\
\text { welfare state expansion } \\
(504)\end{array}$ & 17.44 & 15.26 \\
\hline $\begin{array}{l}\text { Fabric of society - traditional } \\
\text { morality positive ( } 603)\end{array}$ & & & $\begin{array}{l}\text { Welfare and quality of life - } \\
\text { education expansion (506) }\end{array}$ & 2.56 & 1.58 \\
\hline $\begin{array}{l}\text { Fabric of society - law and order } \\
(605)\end{array}$ & 8.72 & 7.37 & $\begin{array}{l}\text { Social groups - labour groups } \\
\text { positive (701) }\end{array}$ & 25.64 & 23.16 \\
\hline $\begin{array}{l}\text { Fabric of society - civic mindedness } \\
\text { positive (606) }\end{array}$ & & & $\begin{array}{l}\text { Freedom and democracy - } \\
\text { democracy (202) }\end{array}$ & & \\
\hline R-total & 13.33 & 23.69 & L-total & 56.92 & 55.79 \\
\hline
\end{tabular}

Data source: Eurobarometer (2010, 2013).

The collected data allows the calculation of the left-right position of the political parties as well as voter policy emphases and their shifts using the (R-L) formula (Table 6).

As indicated by Budge, the advantage of the CMP is its flexibility and its ability to accommodate to every individual research study (Budge 2013). Reflecting upon the political scene in the Czech Republic, with ODS and TOP09 being traditionally right-wing political parties, the line separating the left and right portions of the political spectrum must be established at around a value of -15 . The customised 
Table 6: Party and voter policy position on the left-right scale

\begin{tabular}{|c|c|c|c|c|c|c|}
\hline & ODS & KDU-ČSL & TOP09 & ČSSD & Green & KSČM \\
\hline $\mathbf{2 0 1 0}$ & 9.09 & 4.69 & -6.27 & -12.05 & -20.32 & -31.87 \\
\hline $\mathbf{2 0 1 3}$ & -4.92 & -23.51 & -9.56 & -21.79 & -31.34 & -38.29 \\
\hline
\end{tabular}

Data source: Author's own calculations based on Volkens et al. (2016) and Budge (2013) methodology.

scale also reflects the latest survey of political party positions within the Czech political spectrum (CVVM 2016). ČSSD, the Green Party, and KSČM are then placed in the left part of the political spectrum. With KSČM and the Green Party generally considered as niche parties, no extreme right or extreme left party contested both elections.

The analysis indicates that whereas the policies in all parties' manifestos shifted towards the left, the policies of voters shifted towards the right. Slight discrepancies may be the result of the absence of some data in voter emphasis calculations; it is, however, unlikely that this would have a strong effect on the directions of voter shifts, especially given that these shifts are calculated on the basis of the same available data in 2010 and 2013.

A significant shift was visible in KDU_ČSL's position, which moved from the right part of the political spectrum to the left. This may be due to KDU-ČSL, being traditionally considered a centrist party, oscillating between the two sides. It is shown, however, that the mean voter position inclined towards more left-minded policy preferences during the 2010 elections than all the political parties in their manifestos, including the KSČM. The parties might have shifted their positions more towards voter policy emphasis (see Figure 1). Nevertheless, it is hard to draw any conclusion given the asymmetric nature of the numbers. A significant shift on the left-right scale tends to occur over the long term. It can, therefore, be assumed that parties reflected the long-term policy preferences of the voters, approximating their preferences over the longer period. The direction on the left-right scale seems not to be reflected in the short term, from one election to another. There is no difference in policy shift between niche and mainstream political parties. 
Figure 1: Party and voter policy shifts on the left-right scale

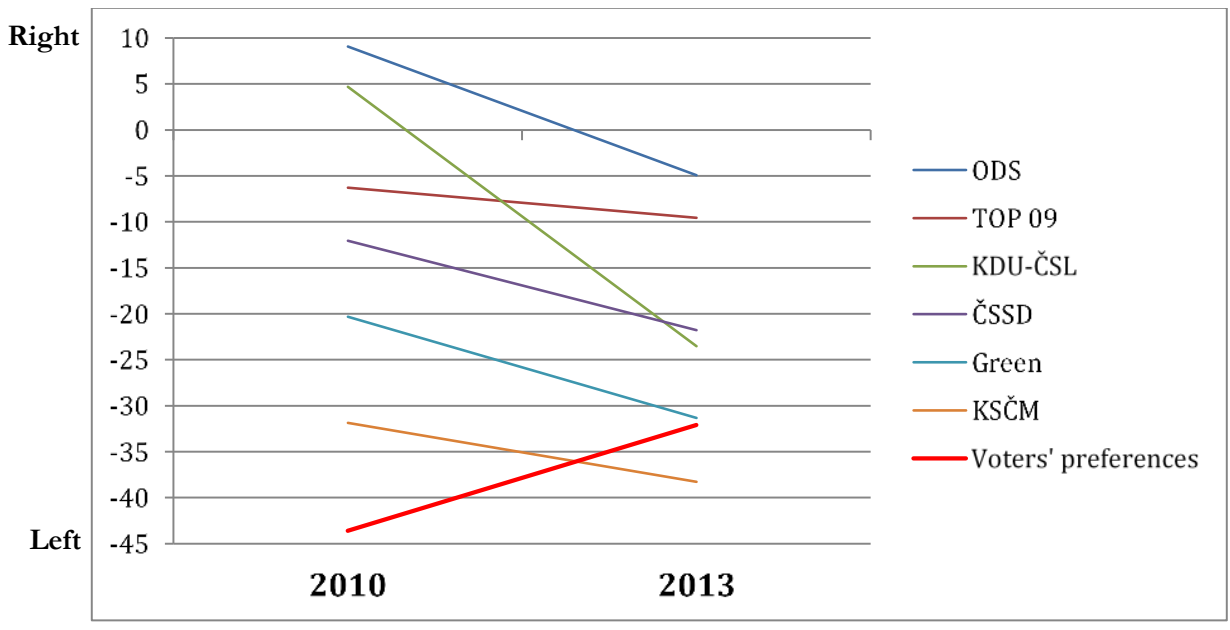

Data source: The Figure illustrates the author's own data calculated in Table 6 on the basis of Volkens et al. (2016) and Budge (2013) methodology.

\section{b. Assessment in the seven policy areas}

The positions of the six political parties that contested both the 2010 and 2013 Czech parliamentary elections were then calculated in the seven main policy areas (as set out in 3a) which are emphasised by the CMP. As stated, these areas include external relations; freedom and democracy; the political system; the economy; the welfare state and quality of life; the fabric of society; and social groups (Volkens et al. 2016: 10-25). Similarly as above, the policy positions of the parties within these areas were calculated on the basis of the percentage of statements in each of the parties' manifestos for the 2010 and 2013 elections fitting each of the above categories. A similar approach was employed using the Eurobarometer data survey (Eurobarometer 2010, 2013) to identify the policy areas of most interest to Czech voters before the 2010 and 2013 elections (see Table 7).

Overall, the results show that while statements in the party manifestos were more likely to be spread over all seven policy areas, the issues depicted by voters as the most important covered only five of seven of the main policy areas. Overall, the percentage level of attention given by voters to these five areas was reflected in political party manifestos (see Figure 2). Voters emphasised the economy and the welfare state and quality of life policy areas the most, with both being reflected in party manifestos. No difference was identified between niche and mainstream political parties. Voters placed slightly more emphasis on social groups.

Given that voter emphasis on freedom and democracy and political systems was not strong enough to be registered by the Eurobarometer survey, the quantitative 
research conducted in the study was limited to the remaining five policy areas. Based on these areas, it examined how shifts in party manifestos reflected shifts in voter policy emphasis.

Table 7: Policy preferences in party manifestos and voter policy emphasis

\begin{tabular}{|c|c|c|c|c|c|c|c|}
\hline & ODS & KDU-ČSL & TOP09 & ČSSD & $\begin{array}{l}\text { Green } \\
\text { party }\end{array}$ & KSČM & $\begin{array}{c}\text { Public } \\
\text { opinion }\end{array}$ \\
\hline \multicolumn{8}{|c|}{ External relations } \\
\hline 2010 & 5 & 10 & 6 & 5 & 6 & 6 & 1 \\
\hline 2013 & 5 & 5 & 5 & 5 & 3 & 9 & 1 \\
\hline \multicolumn{8}{|c|}{ Freedom and democracy } \\
\hline 2010 & 8 & 7 & 5 & 9 & 10 & 11 & 0 \\
\hline 2013 & 8 & 9 & 14 & 5 & 12 & 12 & 0 \\
\hline \multicolumn{8}{|c|}{ Political system } \\
\hline 2010 & 10 & 7 & 13 & 10 & 10 & 5 & 0 \\
\hline 2013 & 8 & 7 & 10 & 6 & 7 & 4 & 0 \\
\hline \multicolumn{8}{|c|}{ Economy } \\
\hline 2010 & 38 & 30 & 36 & 29 & 22 & 30 & 41 \\
\hline 2013 & 36 & 29 & 23 & 23 & 26 & 26 & 49 \\
\hline \multicolumn{8}{|c|}{ Welfare state and quality of life } \\
\hline 2010 & 24 & 21 & 25 & 27 & 36 & 32 & 22 \\
\hline 2013 & 26 & 29 & 31 & 41 & 42 & 32 & 18 \\
\hline \multicolumn{8}{|c|}{ Fabric of society } \\
\hline 2010 & 9 & 18 & 10 & 13 & 8 & 11 & 11 \\
\hline 2013 & 6 & 8 & 10 & 7 & 4 & 10 & 9 \\
\hline \multicolumn{8}{|c|}{ Social groups } \\
\hline 2010 & 5 & 6 & 4 & 7 & 8 & 4 & 26 \\
\hline 2013 & 9 & 12 & 6 & 11 & 6 & 8 & 23 \\
\hline
\end{tabular}

Data source: Comparative Manifesto Project 2016. Figures in the Table were calculated on the basis of CMP coded versions of individual party manifestos CMP available at https://visuals.manifesto-project.wzb.eu/mpdb-shiny/cmp_dashboard_dataset/\#. 
Figure 2: Policy preference in party manifestos and voter policy emphasis

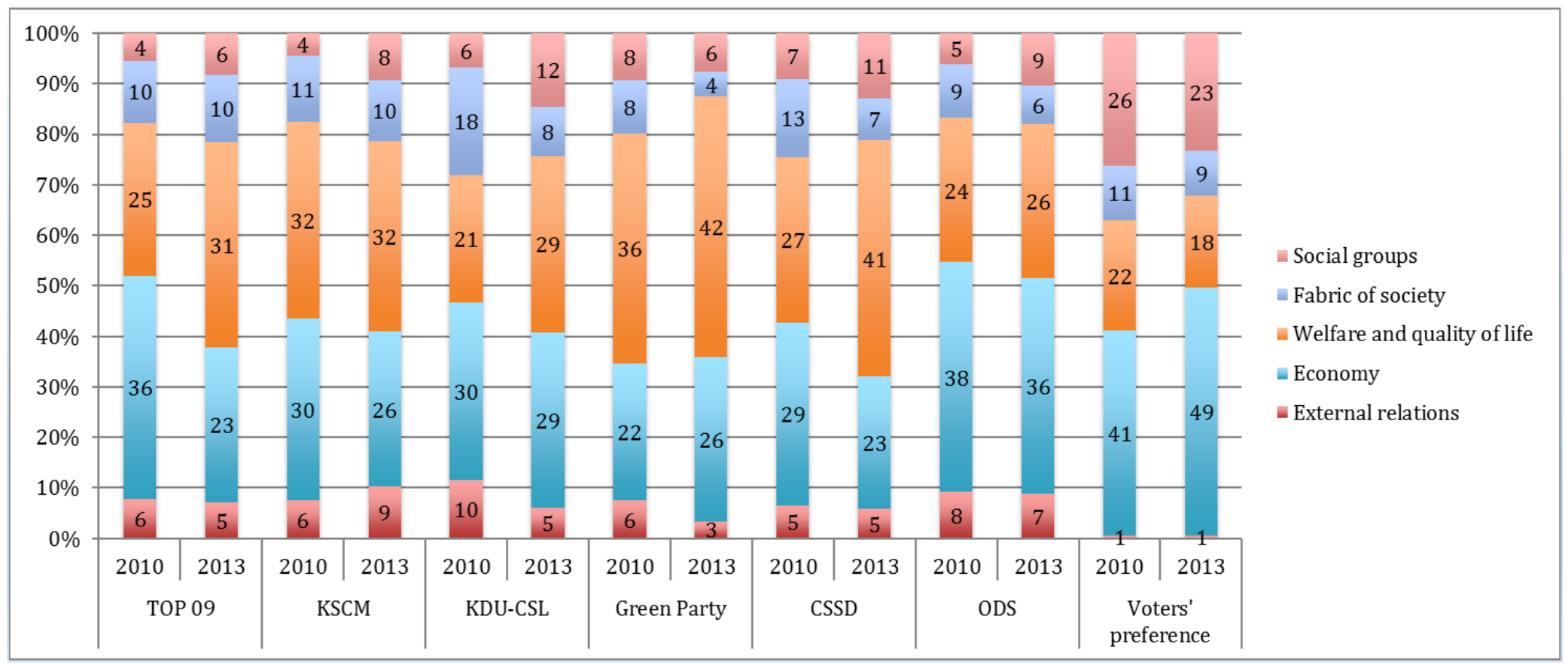

Source: The Figure was developed by the author and it illustrates the data coded in Table 7. 


\section{c. Congruence of shifts in voter policy emphasis and changes in party manifestos}

The results immediately show that each party reflects shifts in voter emphasis in a very different way. Directional analysis was applied to determine the congruence. The measurement, as indicated in Table 2 of the Methodology section, determines how an individual party reflects shifts in voter emphasis in their electoral manifesto. It considers whether the shift is in the same or opposite direction. For example, if voters placed more emphasis on the economy during the 2013 elections than in 2010, was this reflected in the same way in the party manifesto? After the direction of the shift was determined, the extent of the shift and its comparison with the electorate's shift was analysed.

Table 8 shows the results of the analysis, indicating that in about $23 \%$ of cases (7 out of 30) parties were generally responsive to the direction of electorate shifts in particular policy areas. Political parties mostly reflected the opinion of voters in the fabric of society policy area, which, among others, includes migration, currently a 'hot topic' among the general public. The parties were least responsive to the directions of voter emphasis shifts in the two most emphasised areas - the economy and welfare and quality of life. However, as previously indicated, these two areas are the most prominent with respect to voter emphasis as well as in party manifestos, which indicates that parties established their long-term positions to reflect the long-term vision of their voters. However, while voter policy emphasis decreased on welfare and quality of life and increased on the economy, all parties reacted in the opposite way. Similarly, overall, voters in both elections emphasised the economy more than the political parties did, whereas the welfare state agenda seems to have been over-emphasised in party manifestos. As indicated above, congruence was only measured in five policy areas - those for which data were fully available.

Considering the research of Ezrow (2014) and Fossati et al. (2014), amongst other studies, it is worth reiterating that shifts in voter emphasis are not the sole factor that influences or informs party manifestos. The parties need to balance the pressure of public opinion with the pressure of the market, which might lead to directional differences between party shifts and voter shifts in the short-term, i.e. from one election to another (Ezrow 2014). In addition, previous research has proven that levels of income distribution contribute to voter choices (Fossati and Hausermann 2014), which likely affected the over-emphasis placed on the welfare state revealed in this research. The analysis of other factors is outside of the scope of this article, and we refer to it here only to complement to this research and to offer material for further analysis. 
Table 8: Congruence of shifts in voters' policy positions and changes in party manifestos within seven policy areas

\begin{tabular}{|l|c|c|c|c|c|c|c|}
\hline \multicolumn{1}{|c|}{ Policy group } & ODS & $\begin{array}{c}\text { KDU- } \\
\text { ČSL }\end{array}$ & TOP09 & ČSSD & $\begin{array}{c}\text { Green } \\
\text { party }\end{array}$ & KSČM & $\begin{array}{c}\text { TOTAL (per } \\
\text { policy group) }\end{array}$ \\
\hline $\begin{array}{l}\text { External } \\
\text { relations }\end{array}$ & -0.5 & -1.0 & -0.5 & 1.0 & -0.5 & -0.5 & -2.0 \\
\hline Economy & -1.0 & -1.0 & -1.0 & -1.0 & -1.0 & -1.0 & -6.0 \\
\hline $\begin{array}{l}\text { Welfare and } \\
\text { quality of life }\end{array}$ & -0.5 & -1.0 & -1.0 & -1.0 & -1.0 & -0.5 & -5.0 \\
\hline $\begin{array}{l}\text { Fabric of } \\
\text { society }\end{array}$ & 1.0 & 0.5 & 0.0 & 1.0 & 1.0 & 1.0 & 4.5 \\
\hline Social groups & -1.0 & -1.0 & -0.5 & -0.5 & 1.0 & -0.5 & -2.5 \\
\hline $\begin{array}{l}\text { TOTAL (per } \\
\text { party) }\end{array}$ & -2.0 & -3.5 & -3.0 & -0.5 & -0.5 & -1.5 & \\
\hline
\end{tabular}

Data source: Author's own calculations based on the methodology introduced in Table 2 and based on Merrill and Grofman 1999 methodology.

Regarding individual political parties, none of them reflected the voter shift in every policy area. According to the Table 8 , each party evinces only one or two positives values in five policy categories (20-25\%). There are six parties and five policy groups, indicating that congruence between party manifestos and voter shifts was analysed in 30 cases. In seven cases $(23.33 \%)$ the value is positive, meaning that parties reflected voter policy shifts. In 22 cases $(73.3 \%)$ the value is negative indicating that parties moved the opposite direction than the electorate. In one case $(3.33 \%)$ the value remains zero indicating no change in party position. Therefore, party manifestos reflected voter shifts in less than $25 \%$ of cases. The strongest congruence $(-0.5)$ was observed for the Green Party and ČSSD, which reflected voter shifts fully in two policy areas, followed by KSČM (-1.5), ODS (-2) TOP09 $(-3)$ and KDU-ČSL (-3.5). Figure 3 illustrates the directions in voter policy emphasis from the 2010 to 2013 elections and their reflection by the political parties. In the short-term, there was no correlation between the parties' reflections of voter shifts and their positions on the left-right scale. 
Figure 3: Level of congruence in voters' shifts and changes in party manifestos within five policy areas

External Relations

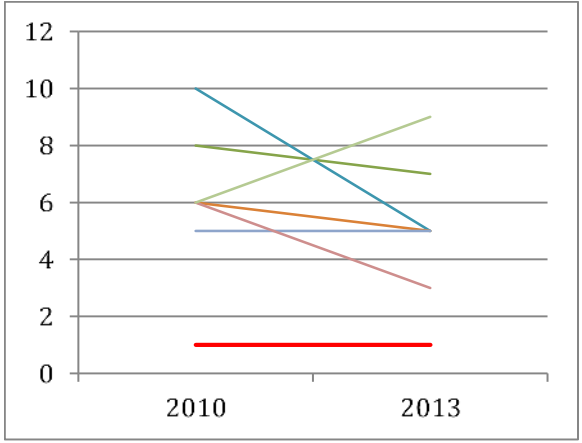

Welfare and quality of life

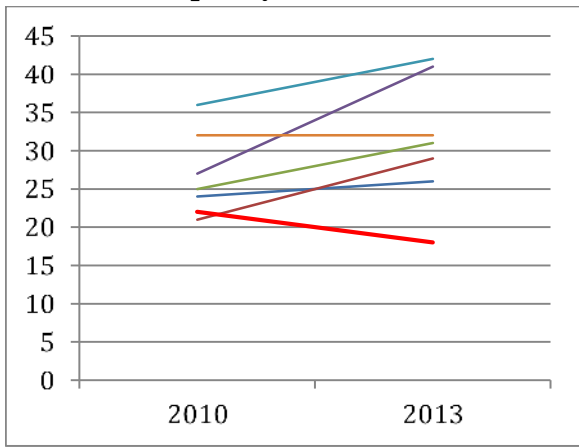

\section{Social Groups}

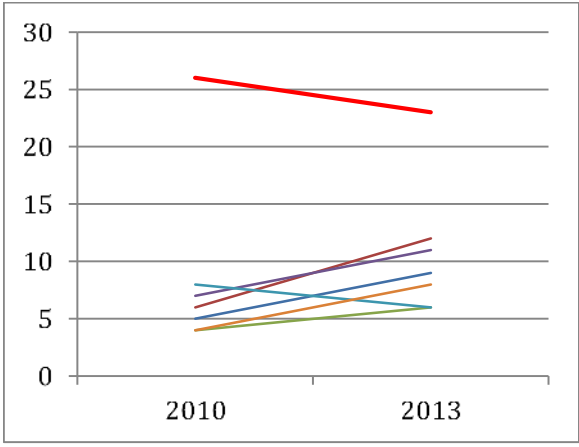

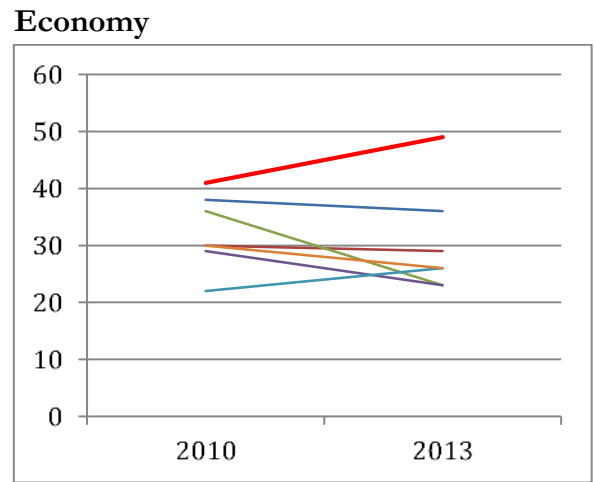

Fabric of society

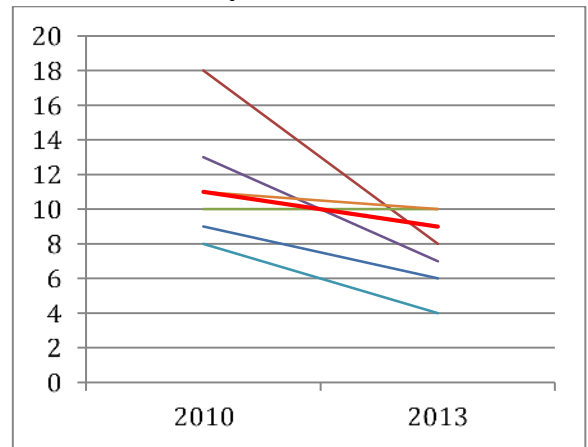

Legend:

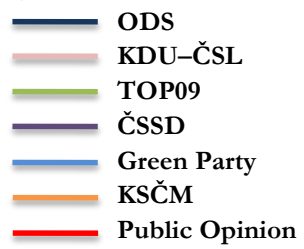

Source: The tables illustrate the results presented in Table 8 - author's own calculations based on the methodology introduced in Table 2 and on the methodology of Merrill and Grofman 1999. 


\section{d. Survey analysis}

As indicated in the Methodology chapter, the Eurobarometer survey only covers top policy areas as emphasised by the voters. This makes the research incomplete, as voters' policy shifts are not visible in the areas of human rights, freedom and democracy, and political system, and only a very small shift is discernible in the external policy area. To cover this gap, the research employs analysis using the CVVM and STEM surveys, as well as the EU-focused Eurobarometer surveys.

The surveys reveal the following information:

Satisfaction with the state and the functioning of democracy: Satisfaction with the functioning of democracy dropped from $32 \%$ in 2009 to $26 \%$ in 2013. Trust in democratic development, the work of political parties, and internal politics in general declined from 2010 to 2013. In 2013, only $32 \%$ of voters considered that political parties guaranteed democratic policies, compared to $48 \%$ in 2009 (STEM 2013: 2).

EU membership (External relations): In 2013, $74 \%$ of Czech voters considered EU membership to be a 'good thing'; $59 \%$ considered Czech participation in EU structures as useful (CVVM 2013: 2-3). According to the Eurobarometer survey, in $2009,50 \%$ of Czech voters tended to trust the EU, compared to $42 \%$ in 2013. According to the Eurobarometer survey, $55 \%$ of Czech voters felt like EU citizens in 2010 and $54 \%$ felt this way in 2013 (Eurobarometer 2010: 16; Eurobarometer 2013: 12).

Dissatisfaction with the state of the economy increased from $52 \%$ in 2009 to $68 \%$ at the beginning of 2013 (CVVM 2013a: 2-4). According to the Eurobarometer survey, in $2013,85 \%$ of voters considered the state of the national economy to be bad (Eurobarometer 2013: 19).

Satisfaction with life (welfare and quality of life) remained at nearly the same level with no significant decreasing or increasing trends. According to the CVVM survey, about $18 \%$ of voters considered the economic situation of their household to be bad, both in 2011 and 2013 (CVVM 2013a: 4).

The slight decrease in satisfaction with democracy seems to be reflected in a slight increase in references to democracy in the manifestos of three political parties - the Green party, ČSSD, and KSČM, and a significant increase in the TOP09 manifesto. Voters of the centre-right parties (ODS, TOP09), nevertheless, evinced the highest level of satisfaction with the democratic functioning of their state - 51 and $55 \%$ in 2010 and 56 and $57 \%$ in 2013, respectively (STEM 2013: 2). By contrast, voters of left-wing parties, notably ČSSD and KSČM, demonstrated the lowest satisfaction with the functioning of democracy (22 and $11 \%$ in 2010, and 11 and $19 \%$ in 2013, respectively; see STEM 2013: 2). Therefore, increases or decreases in the emphasis on democracy by political party manifestos did not reflect in a coherent manner shifts in voter emphasis. The satisfaction with democracy, 
however, also reflects education and age group, which goes beyond the scope of this research.

Dwindling public trust in EU institutions was reflected in TOP09 and ČSSD manifestos through an increase in the number of positive references to the EU. In contrast, the Green party, KDU-ČSL, and ODS manifestos exhibited decreases in their positive references to the EU (see Table 9). KSČM voters were the most critical towards the EU (CVVM 2013: 2), which may explain the lowest percentage of positive references to the EU during times that voters were shifting towards a more critical position. Voters of TOP09 were the most positive, which correlates with the number of positive EU references in the party manifesto, which was among the highest among all the analysed parties. The shifts within this category were, therefore, more likely to be affected by party constituency position, rather than mean voter position. Nevertheless, the shifts within this category, and similarly in the overall external policy area, were likely to be affected on the broader scale, which attests to the lack of congruence between the parties' manifestos and voter emphasis. Given that the article only focuses on shifts in voter preferences, the assessment remains limited.

Table 9: Shifts in positive references to the EU in party manifestos (in \%)

\begin{tabular}{|c|c|c|c|c|c|c|}
\hline & ODS & KDU-ČSL & TOP09 & ČSSD & Green party & KSČM \\
\hline 2010 & 1.54 & 2.9 & 1.65 & 0.93 & 1.7 & 0 \\
\hline 2013 & 0.31 & 0.89 & 1.94 & 1.96 & 0.46 & 0 \\
\hline
\end{tabular}

Data source: Comparative Manifesto Project 2016. Figures in the Table were calculated based on CMP coded versions of individual party manifestos CMP available at https://visuals.manifesto-project.wzb.eu/mpdb-shiny/cmp_dashboard_dataset/\#.

The two last categories depicted in the quantitative analyses indicate the great dissatisfaction of voters with the economy. As already stated, this was widely reflected in party manifestos, which attributed this area the highest number of policy references. Parties also increased references to welfare and quality of life despite there being no significant shifts in voter emphasis.

\section{Conclusions}

This article analysed the extent to which political parties in the Czech Republic reflected voter policy emphasis in the short-term, from the 2010 to 2013 parliamentary elections. The article focused explicitly on political parties that contested both the 2010 and 2013 elections. Employing the CMP methodology, the research first compared shifts in the positions of voters with shifts in party manifestos on the left-right political scale. Secondly, it focused on five main policy 
areas and examined the congruence of shifts in voter and party positions. In view of some gaps in the available data, the quantitative research could not cover all areas. Survey analysis was, therefore, employed to fill the gap and confirm the main trend.

The analysis revealed shifts in party manifestos towards the left on the leftrightscale, while voter emphasis shifts exhibited the opposite direction. Given that the research focused only on a short period, this may confirm the assumption that ideological shifts in party policy tend to occur over the long term. Despite the contrasting directions of shifts, it seems that parties aimed to align their manifestos to the long-term preferences of voters, which have been more orientated towards the left or centre. There was no difference in the short-term between niche and mainstream political parties.

Additionally, some discrepancy may be attributed to the CMP methodology for calculating the left-right scale. As indicated, the main criticism of the data is that they tell us what parties publically say without looking fully into their actual ideological positions (Mc Donald and Mendés 2001: 90). The same is deemed to be true in calculating the ideological positions of voters. This article, nevertheless, analyzed party manifestos - what the parties publically say. Looking into party positions outside of the manifestos would go beyond its scope. The CMP methodology was therefore deemed fully sufficient.

The research conducted on seven main policy areas - external relations, freedom and democracy, the political system, the economy, the welfare state and quality of life, the fabric of society, and social groups - confirmed that party manifestos covered a wider spectrum of policy areas than the range of areas of particular interest to voters. Two policy areas (freedom and democracy and political system) were not given enough consideration by the voters to allow for their inclusion in the quantitative analysis. The two topics considered most important by voters - the economy, and welfare/quality of life - were reflected in similar percentages across all party manifestos. No difference was identified between niche and mainstream political parties.

In the survey analysis, the article depicted democracy and EU-membership as being largely affected by the party constituency position. This plays into the fact that the mean voter position does not consider democracy and external relations as the most important policy topics, relegating them behind the economy and welfare considerations. While the economy and welfare represent the overall interest, democracy and external relations are based more on ideological positions and, therefore, are more reflected in specific party constituency expectations.

While this article took note of partisan constituency and general electorate models, the lack of available data did not allow for a quantitative analysis beyond shifts in mean voter position. Congruence between shifts in emphases among party supporters and shifts in party policy was only examined in the survey analysis part 
of the research and focused on the democracy and EU institutions policy areas only. The research revealed some congruence between party position shifts and electorate positions shifts. The congruence, however, remained inconsistent. Different parties reacted differently to changes in voter emphasis. A general decrease in public trust in EU institutions led to a decrease in positive references to the EU by the generally euro-sceptic ODS, but an increase in positive references by the more pro-EU ČSSD. The direction of the shift therefore seems to reflect the ideological position of the party.

This appears to be true overall - each political party reflected shifts in voter emphasis in a very different way, with Czech political parties being responsive to voter shifts in about one quarter of cases in the short-term. Parties tend to respond to the direction of voter policy emphasis over the longer term, forming their position over time. The strongest congruence between voter and party shifts was found for the Green Party, ČSSD and KSČM. Taking into account other parts of the research, this indicates that there was no difference between niche and mainstream party shifts in the 2010 and 2013 parliamentary elections in the Czech Republic. It can be concluded that in the short-term, Czech parties that are generally classified as niche parties are inclined to tilt more towards mainstream policies. In considering this, it is worth highlighting again that the parties that contested both the 2010 and 2013 Czech parliamentary elections were the only ones analysed in this article, and the responsiveness of other more extreme niche parties may deviate from the findings presented here.

Overall, the limited reflection of shifts in voter policy emphasis by political parties seems to be similar for political parties within the Central and Eastern European space. Citizen's preferences tend to be generally stable and develop over the long term; therefore, dramatic policy changes by parties may be risky as they destabilise voter perceptions. In order to stay in power, political parties need to take an active role in adapting their policies to the wishes of the electorate (Gherghina 2009: 6, 12-22; Colomer 2001: 130-138) One could perhaps claim, on the basis of the paper's findings, that the less stable party-political landscape in the Czech Republic (and possibly other CEE countries as well) reflects the limited active parties' adaptation to the shifts in voter policy emphasis.

Political parties have become a widely studied area of academic research. However, the systematic research of party responses to shifts in voter policy emphasis and its individual categories is lacking. This is due, in particular, to the lack of available data, which was similarly a challenge to this research. This article hopes to open the door to more detailed systematic studies of this phenomenon. Comparative research of the congruence between shifts in voter policy emphasis and party manifestos in general and with respect to individual policy areas over the short and long term could provide further explanations of party political behaviour. 


\section{References}

Adams, James et. al. 2006. "Are Niche Parties Fundamentally Different from Mainstream Parties? The Causes and the Electoral Consequences of Western European Parties' Policy Shifts, 1976-1998." American Journal of Political Science 50(3): 513-529. DOI: 10.1111/j.1540-5907.2006.00199.x

Adams, James, Lawrence Ezrow and Zeynep Somer-Topcu. 2011. "Is anybody listening? Evidence that voters do not respond to European parties' policy statements during elections." American Journal of Political Science 55(2): 370-382. DOI: 10.1111/j.15405907.2010.00489.x

Benoit, Kenneth et al. 2012. "How to scale coded text units without bias: A response to Gemenis”. Electoral Studies 31(3): 605-608. DOI: 10.1016/j.electstud.2012.05.004

Budge, Ian et al. 1992. Party, Policy and Government Coalitions. London: Sage.

Budge, Ian et al. 2001. Mapping policy preferences: Estimates for parties, electors, and governments 1945-1998, Vol. 1. Oxford: Oxford University Press.

Budge, Ian. 2013. "The Standard Right-Left Scale." Essex University. https://manifestoproject.wzb.eu/down/papers/budge_right-left-scale.pdf.

Budge, Ian and Michael McDonald. 2012. 'Conceptualising and measuring 'centrism' correctly on the Left-Right scale (RILE) - Without systematic bias: A general response by MARPOR”. Electoral Studies 31(3): 609-612. DOI: 10.1016/j.electstud.2012.05.008

Busch, Kathrin Barbara. 2016. "Estimating parties' left-right positions: Determinants of voters' perceptions' proximity to party ideology." Electoral studies 41: 159-178. DOI: 10.1016/j.electstud.2016.01.003

Chytilek, Roman. 2014. Politický prostor a politická témata"studie k soutěrú politických stran (Political space and political topics: study of the political parties' competition). Brno: Centrum pro stadium demokracie a kultury (Centre for the Study of Democracy and Culture).

Colomer, Josep M. 2001. "Disequilibrium Institutions and Pluralist Democracy." Journal of Theoretical Politics 13(3): 235-247. DOI: 10.1177/095169280101300301

Comparative Manifesto Project. 2016. Accessed June 5. https://manifestoproject.wzb.eu/.

CVVM (Centrum pro výzkum veřejného mínění [The centre for public opinion research]). 2013. "Hodnocení členství v EU a postoj k euro v středoevropském srovnání - léto 2013 (EU membership evaluation and the position towards the Euro in Central-European comparison)". Tisková zpráva (Press Release), pm131009. http://cvvm.soc.cas.cz/media/c om_form2content/documents/c1/a7097/f3/pm131009.pdf.

CVVM. 2013a. “Občané o hospodářské situaci ČR a o životní úrovni svých domácností zárý 2013 (Citizens on the economic situation in the Czech Republic and on the situation in their households)“. Tisková apráva (Press Release), ev131004. http://cvvm.soc.cas.cz/ media/com_form2content/documents/c1/a7095/f3/ev131004.pdf.

CVVM. 2016. "Sebezařazení na levo-pravé škále politické orientace - duben 2016 (Self identification at the left-rightscale of the political orientation - April 2016) ". Tisková zpráva (Press Release), po160517. http://cvvm.soc.cas.cz/media/com_form2content/ documents/c1/a7559/f3/po160517.pdf.

Eurobarometer. 2010. Eurobarometer 73: Public Opinion in the European Union: first results. August 2010. http://ec.europa.eu/public_opinion/archives/eb/eb73/eb73_en.htm. 
Eurobarometer. 2013. Eurobarometer 80: Public Opinion in the European Union: first results. December 2013. http://ec.europa.eu/public_opinion/archives/eb/eb80/eb80_en.htm. Ezrow, Lawrence. 2014. "Responding to Voters or Responding to Markets? Political Parties and Public Opinion in an Era of Globalization. International Studies Quarterly 58: 816-827. DOI: $10.1111 /$ isqu.12129

Ezrow, Lawrence et. al. 2011. "Mean Voter Representation and Partisan Constituency Representation: Do Parties Respond to the Mean Voter Position or to their Supporters?" Party Politics 17 (3): 275-301. DOI: 10.1177/1354068810372100

Fossati, Flavia and Silja Hausermann. 2014. "Social Policy Preferences and Party Choice in the 2011 Swiss Elections." Political Science Review 20(4): 590-611. DOI: $10.1111 /$ spsr. 12115

Gherghina, Sergiu. 2009. "Still Waters Run Deep: Party Organization and Electoral Stability in New Democracies." ECPR Joint Sessions. Lisbon, April 14-19. https:/ / ecpr.eu/Filestore/PaperProposal/00696bca-cb94-49ac-8577-9ff2aa1896a6.pdf. Havlík, Vlastimil and Petr Voda. 2016. "The Rise of New Political Parties and ReAlignment of Party Politics in the Czech Republic." Acta Politologica 8(2): 119-144.

Chytilek, Roman, and Otto Eibl. 2011. "České politické strany v politickém prostoru (Czech political parties in the policy space)." Sociologický ćasopis (Czech Sociological Review) 47(1): 61-88.

Klingemann, Hans-Dieter et al. 2006. Mapping Policy Preferences II. Estimates for Parties, Electors, and Governments in Eastern Europe, the European Union and the OECD, 1990-2003. Oxford: Oxford University Press.

Kunštát, Daniel. 2004. "Parametry stranické identity českých voličů (Characteristics of party identity of the Czech voters)." Naše společnost (Our society) 2(2): 18-21.

Laver, Michael and Ian Budge (eds.). 1992. Party Policy and Government Coalitions. Houndmills, Basingstoke, Hampshire: The MacMillan Press.

Leimgruber, Philipp, Dominik Hangartner and Lucas Leemann. (2010): "Comparing Candidates and Citizens in the Ideological Space." Swiss Political Science Review 16(3): 499_ 531. DOI: 10.1002/j.1662-6370.2010.tb00439.x

Lowe, Will, et al. 2011. "Scaling policy preferences from coded political texts." Legislative studies quarterly 36(1): 123-155. DOI: 10.1111/j.1939-9162.2010.00006.x

Maškarinec, Pavel and Petr Bláha. 2014. "For whom the Bell Tolls: Grievance Theory and the Rise of New Political Parties in the 2010 and 2013 Czech Parliamentary Elections." Sociologia 46(6): 706-731.

McDonald, Michael and Silvia M. Mendés. 2001. "The policy space of party manifestos." In Michael Laver (ed.). Estimating the Policy Position of Political Actors. London: Routledge, 90-114

Merrill, Samuel and Bernard Grofman. 1999. A Unified Theory of Voting: Directional and Spatial Models. Cambridge: Cambridge University Press.

Meguid, Bonnie M. 2005. "Competition Between Unequals: The Role of Mainstream Party Strategy in Niche Party Success." American Political Science Review 99(3): 347-359. DOI: 10.1017/S0003055405051701

Meyer, Thomas M. 2013. Constraints on party policy change. Colchester: ECPR Press, University of Essex. 
Schumacher, Gijs, Catherine E.de Vries and Barbara Vis. 2013. "Why Political Parties Change Their Positions: Environmental Incentives \& Party Organisation. The Journal of Politics 57 (2): 464-477. DOI: 10.1017/S0022381613000145

STEM. 2009. "Hodnocení stavu společnosti za rok 2009 (Evaluation of the state of the society in 2009)", January 2010. https://www.stem.cz/vysvedceni-ceske-spolecnosti-zarok-2009/.

STEM. 2013. "Nespokojenost s fungováním demokracie a činností politických stran jako záruky demokracie trvá (Dissatisfaction with the democracy functioning and functioning of political parties to guarantee democracy prevail)", May 14. https://www.stem.cz/fungovani-demokracie-u-nas/.

Stimson, James, Michael MacKuen and Robert Erikson. 1995. "Dynamic of representation." Political Science Review 89: 543-565. DOI: 10.2307/2082973

Volkens, Andrea et al. 2016. The Manifesto Data Collection. Manifesto Project (MRG/CMP/MARPOR). Version 2016a. Berlin: Wissenschaftszentrum Berlin für Sozialforschung (WZB).

Volkens, Andrea et al. 2016a. "Manifesto Project Dataset - List of Coded Documents," 34-37. In Andrea Volkens et al. The Manifesto Data Collection. Manifesto Project (MRG/CMP/MARPOR). Version 2016a. Berlin: Wissenschaftszentrum Berlin für Sozialforschung (WZB).

Wagner, M. 2012. "Defining and measuring niche parties." Party Politics 18(6): 845-864. DOI: $10.1177 / 1354068810393267$

Walczak, Agnieszka, Wouter van der Brug and Catherine E. de Vries. 2012. "Long- and short-term determinants of party preferences: Inter-generational differences in Western and East Central Europe." Electoral studies 31: 273-284. DOI: 10.1016/j.electstud.2011.11.007

Warwick, Paul V. 2010. "Bilateralism or the median mandate?: an examination of rival perspectives on democratic governance. European Journal of Political Research 49(1): 1-24. DOI: $10.1111 / \mathrm{j} .1475-6765.2009 .01878 . x$ 


\section{Appendices}

\section{Appendix I: Comparative Manifesto Project - Categories and sub-categories in seven policy areas (including codes)}

\section{External Relations}

101 Foreign Special Relationships: Positive

102 Foreign Special Relationships: Negative

103 Anti-Imperialism: Positive

103.1 State Centred Anti-Imperialism

103.2 Foreign Financial Influence

104 Military: Positive

105 Military: Negative

106 Peace: Positive

107 Internationalism: Positive

108 European/LA Integration: Positive

109 Internationalism: Negative

110 European/LA Integration: Negative

\section{Freedom and Democracy}

201 Freedom and Human Rights: Positive

201.1 Freedom

201.2 Human Rights

202 Democracy

202.1 General: Positive

202.2 General: Negative

202.3 Representative Democracy: Positive

202.4 Direct Democracy: Positive

203 Constitutionalism: Positive

204 Constitutionalism: Negative

\section{Political System}

301 Decentralisation: Positive

302 Centralisation: Positive

303 Governmental and Administrative

Efficiency: Positive

304 Political Corruption: Negative

305 Political Authority: Positive

305.1 Political Authority: Party Competence

305.2 Political Authority: Personal

Competence

305.3 Political Authority: Strong government

305.4 Pre-Democratic Elites: Positive

305.5 Pre-Democratic Elites: Negative

305.6 Rehabilitation and Compensation

\section{Economy}

401 Free-Market Economy: Positive
412 Controlled Economy: Positive

413 Nationalisation: Positive

414 Economic Orthodoxy: Positive

415 Marxist Analysis: Positive

416 Anti-Growth Economy: Positive

416.1 Anti-Growth Economy: Positive

416.2 Sustainability: Positive

\section{Welfare and Quality of Life}

501 Environmental Protection: Positive

502 Culture: Positive

503 Equality: Positive

504 Welfare State Expansion

505 Welfare State Limitation

506 Education Expansion

507 Education Limitation

\section{Fabric of Society}

601 National Way of Life: Positive

601.1 General

601.2 Immigration: Negative

602 National Way of Life: Negative

602.1 General

602.2 Immigration: Positive

603 Traditional Morality: Positive

604 Traditional Morality: Negative

605 Law and Order

605.1 Law and Order: Positive

605.2 Law and Order: Negative

606 Civic Mindedness: Positive

606.1 General

606.2 Bottom-Up Activism

607 Multiculturalism: Positive

607.1 General

607.2 Immigrant Integration: Diversity 607.3

Indigenous rights: Positive

608 Multiculturalism: Negative

608.1 General

608.2 Immigrant Integration: Assimilation

608.3 Indigenous rights: Negative

\section{Social Groups}

701 Labour Groups: Positive 
402 Incentives: Positive

403 Market Regulation: Positive

404 Economic Planning: Positive

405 Corporatism: Positive

406 Protectionism: Positive

407 Protectionism: Negative

408 Economic Goals

409 Keynesian Demand Management:

Positive

410 Economic Growth

411 Technology and Infrastructure: Positive
702 Labour Groups: Negative

703 Agriculture and Farmers

703.1 Agriculture and Farmers: Positive

703.2 Agriculture and Farmers: Negative

704 Middle Class and Professional

Groups: Positive

705 Minority Groups: Positive

706 Non-Economic Demographic

Groups: Positive

Note: Reprinted from Werner, Arnika, LaCewell Onawa, Volkens Andrea. 2015. Manifesto Coding Instructions (5th revised edition). Available at https://manifestoproject.wzb.eu/ down/papers/handbook_2014_version_5.pdf (at page 8).

\section{Appendix II: Original Eurobarometer survey data for the Czech Republic}

\begin{tabular}{|lcc|}
\hline & May-10 & May-13 \\
\hline Unemployment & $50 \%$ & $44 \%$ \\
Economic situation & $53 \%$ & $36 \%$ \\
Crime & $17 \%$ & $14 \%$ \\
Rising prices/inflation & $22 \%$ & $30 \%$ \\
Healthcare/social security & $13 \%$ & $11 \%$ \\
Immigration & $4 \%$ & $3 \%$ \\
Pensions & $14 \%$ & $14 \%$ \\
Taxation & $5 \%$ & $6 \%$ \\
The educational system & $5 \%$ & $3 \%$ \\
Housing & $7 \%$ & $4 \%$ \\
Terrorism & $1 \%$ & $1 \%$ \\
The environment & $2 \%$ & $2 \%$ \\
Energy & $3 \%$ & \\
Defence/Foreign Affairs & $1 \%$ & \\
Government debt & & $22 \%$ \\
\hline
\end{tabular}

Note: Table includes the original Eurobarometer survey data for the Czech Republic collected in May 2010 and May 2013 (Eurobarometer 2010: 11; Eurobarometer 2013: 20). Survey respondents were asked to name the two most important issues faced by their country. The survey includes the issues mentioned most frequently (in \%). 